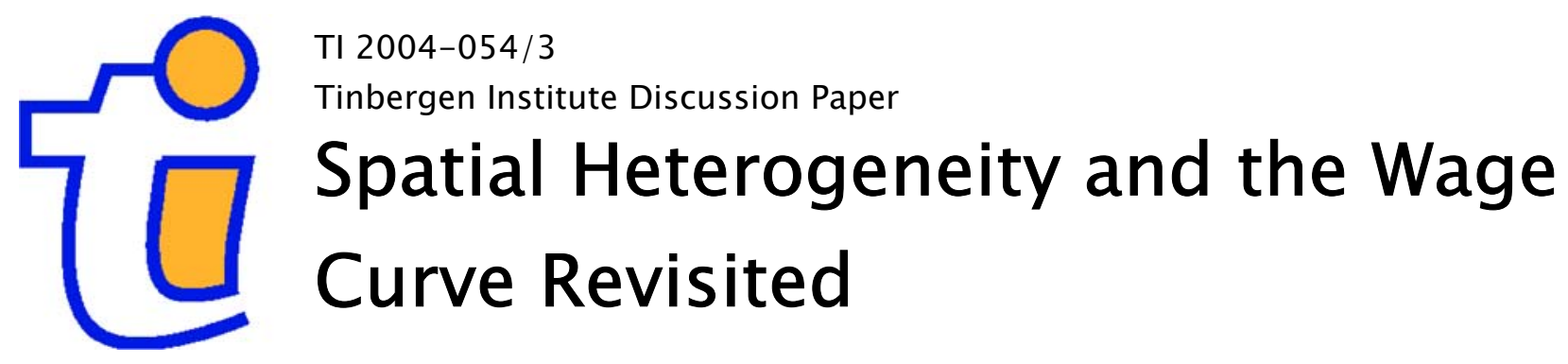

Simonetta Longhir

Peter Nijkamp'

Jacques Poot ${ }^{2}$

12 Faculty of Economics and Business Administration, Vrije Universiteit Amsterdam, and Tinbergen Institute,

2 University of Waikato, Hamilton, New Zealand. 


\section{Tinbergen Institute}

The Tinbergen Institute is the institute for economic research of the Erasmus Universiteit Rotterdam, Universiteit van Amsterdam, and Vrije Universiteit Amsterdam.

Tinbergen Institute Amsterdam

Roetersstraat 31

1018 WB Amsterdam

The Netherlands

Tel.: $\quad+31(0) 205513500$

Fax: $\quad+31(0) 205513555$

Tinbergen Institute Rotterdam

Burg. Oudlaan 50

3062 PA Rotterdam

The Netherlands

Tel.: $\quad+31(0) 104088900$

Fax: $\quad+31(0) 104089031$

Please send questions and/or remarks of nonscientific nature to driessen@tinbergen.nl.

Most TI discussion papers can be downloaded at http://www.tinbergen.nl. 


\title{
Spatial Heterogeneity and the Wage Curve Revisited*
}

\author{
Simonetta Longhi \\ Tinbergen Institute, Amsterdam, The Netherlands \\ Peter Nijkamp \\ Free University, Amsterdam, The Netherlands \\ Jacques Poot ${ }^{\#}$ \\ University of Waikato, Hamilton, New Zealand
}

\begin{abstract}
Most 'wage curve' studies treat local labour markets as independent 'islands' in the national economy. However, when a local labour market is in close proximity of other labour markets, a local shock that increases unemployment may not lead to lower pay rates if employers fear outward migration of their workers. Hence, the unemployment elasticity of pay will be greater, the more isolated the local labour market is. Wages are also expected to be higher in regions that interact strongly with other regions. These hypotheses are confirmed by means of an estimation of wage curves with data for 327 regions of western Germany over the period 1990-97.
\end{abstract}

JEL classification: J21, J30, R23

Key words: Unemployment, wage formation, spatial analysis, local monopsony, Germany

\footnotetext{
* Comments by Thomas de Graaff and Raymond Florax on a draft of this paper are gratefully acknowledged.

\# Corresponding author. Postal address: Population Studies Centre, University of Waikato, Private Bag 3105, Hamilton, New Zealand. E-mail:.jpoot@waikato.ac.nz
} 



\title{
Spatial Heterogeneity and the Wage Curve Revisited
}

\begin{abstract}
Most 'wage curve' studies treat local labour markets as independent 'islands' in the national economy. However, when a local labour market is in close proximity of other labour markets, a local shock that increases unemployment may not lead to lower pay rates if employers fear outward migration of their workers. Hence, the unemployment elasticity of pay will be greater, the more isolated the local labour market is. Wages are also expected to be higher in regions that interact strongly with other regions. These hypotheses are confirmed by means of an estimation of wage curves with data for 327 regions of western Germany over the period 1990-97.
\end{abstract}

\section{Introduction}

The efficient functioning of labour markets is a key concern of public policy. During the last two decades, many governments of developed economies have adopted dedicated policies that aim at enhancing labour market flexibility. The objective of such policies is not only to reduce levels of unemployment, but also to improve the countries' competitive position in increasingly globalised markets. Labour market rigidity was perceived to be particularly severe in Western Europe and in Australasia, where governments aspired to the flexibility experienced by employers and workers in the US labour market. There was, however, by no means a unique set of policies adopted to enhance labour market flexibility, as each country had to take into account its own rather unique structural and institutional characteristics. Thus, a variety of 'models' of reform emerged, such as the 'rhineland model' in Germany, the 'kiwi model' in New Zealand, the 'polder model' in The Netherlands and the 'bulldog model' in the United Kingdom (see e.g. Freeman, 1998; Gorter and Poot, 1999).

Wherever labour market reform was implemented, it became apparent that there was not only a price to pay in terms of a growing personal income inequality, but also in terms of growing regional diversity (e.g. Karagedikli et al., 2000; Dohse et al., 2002). This necessitated the need for a fresh look at prevailing regional economic policies.

A central question in this context is the extent to which local labour markets exhibit non-competitive features. If local labour markets are competitive, the growing inequality and regional divergence observed in recent years may be merely a transitional phenomenon. Factor mobility and interregional trade may in this case diminish personal and spatial differentials in the long run. If, on the other hand, local employers face upward sloping labour supply curves and if there is information 
asymmetry in the labour market and/or externalities leading to spatial agglomeration, the greater spatial inequality following reform may be rather persistent. Specific policies may then be needed to overcome market failures.

The empirical evidence for non-competitive features of local labour markets is rather indirect and incomplete. An interesting example in this context is an empirical phenomenon referred to as the 'wage curve'. Blanchflower and Oswald (1990) found, using American and British micro data, an inverse relationship between the level of pay of individuals and the local unemployment rate and labelled this relationship the wage curve. Their later research (Blanchflower and Oswald, 1994) and the research of other investigators, using similar data for other countries, provided further evidence for the existence of such a relationship. ${ }^{1}$ Nijkamp and Poot (2002) confirmed by means of a meta-analysis of the international evidence that the wage curve is a robust phenomenon. There are several explanations possible for this relationship. Among these, efficiency wage or labour turnover cost explanations that feature individual employers facing upward sloping supply curves in local labour markets are considered the most plausible (see also Card, 1995, and the short review in next section of this paper).

The theory of monopsony has gained increasing attention in recent years (see Boal and Ransom, 1997, and Manning, 2003), but outright monopsony would be a rather extreme market form in that most firms face some competition in their recruitment while barriers to entry into specific markets have been reduced in recent years. ${ }^{2}$ It is therefore more likely that firms engage in monopsonistic or oligopsonistic competition in which there is free entry, but the establishment of new firms is constrained by start up costs, firms face costs of recruitment and training, and workers face varying costs of job search, commuting or migration, dependent on their residential location and their own characteristics. In such labour markets, wages and unemployment are likely to be inversely related (Bhaskar and To, 1999) and this relationship may be reinforced by agglomeration effects (Sato, 2000).

\footnotetext{
${ }^{1}$ For example, Blackaby and Hunt (1992), Winter-Ebmer (1996), Bratsberg and Turunen (1996), Janssens and Konings (1998), Baltagi and Blien (1998), Kennedy and Borland (2000), Papps (2001), Boushey (2002), Montuenga et al. (2003), and Ikkaracan and Selim (2003).

2 "One-company towns" are the classic example of pure monopsony. In the modern economy, they are no longer common, except as a legacy of a communist past in transitional economies. Rama and Scott (1999) show that one-company towns in Kazakhstan face upward sloping labour supply curves.
} 
Much of the existing wage curve literature considers local labour markets as independent 'islands' in the national economy. If the wage curve is the result of monopsonistic competition, we would expect that the extent to which employers face upward sloping labour supply curves will depend on the employment opportunities in surrounding regions and the interregional cost of commuting, or migration. The purpose of this paper is therefore to investigate spatial effects in wage curves.

There is as yet little empirical evidence on this. Using German data, Buettner (1999a) tested whether the wage curve could be extended by including a spatial lag of wages on the right hand side of the earnings equation or by considering spatial error correlation in the model. He found strong support for the former hypothesis, but not for the latter. Morrison et al. (2003) found evidence of the effect of labour market isolation on the wage curve in the New Zealand context through introducing the weighted average of travel time by road to other local labour markets as an additional explanatory variable in the earnings equation. In this paper, we will reconsider spatial effects in the wage curve, using data for 327 regions of western Germany over the period 1990-97. We consider the wage curve as indicative of local monopsonistic competition in the labour market and test several, previously unexplored, hypotheses that can be derived from this point of view.

The next section briefly reviews the theoretical explanations for the wage curve and the likely implications of spatial dependence. Section 3 reports on the estimation of a wage curve with data for 327 regions of western Germany over the 1990-97 period. Section 3 also reviews some of the specification issues involved in estimating such a wage curve. Section 4 provides evidence on a range of spatial effects that are consistent with the notion that employers in local labour markets engage in monopsonistic competition. The final section sums up and suggests avenues for further research in this area.

\section{Implications of monopsonistic local labour markets}

What determines wages at the local labour market level? There are likely to be many factors, the importance of which may vary across countries (see, e.g., Molho, 1992). We use for our empirical research a dataset that provides statistical information on the regions of the former West Germany (excluding West Berlin). Consequently, we will confine ourselves to factors relevant to those regions. Buettner (1999b) discusses regional wage formation in Germany in some detail. 
For the majority of industries in Germany, wages are negotiated at the industry level by bargaining between employer representatives and unions. These negotiations lead to a set of collective agreements that may only apply to union members, but in practice are often extended to non-union members. These collective agreements act as a floor for wage outcomes, as there are various sources of regional wage flexibility. Firstly, there may be regionally-specific collective contract wages, although the incidence of regional agreements is not that great (Buettner, 1999b). Of course, there may be also some flexibility built into the collective agreements that enable employers to vary wages somewhat across regions. Furthermore, flexibility is introduced if agreements are only weakly enforced. In any case, the collectively agreed wage levels are only binding when the competitive wage would be less than the union wage. If there is a shortage of labour, a wage gap may emerge in which firm-specific agreements lead to wages being paid that are higher than the national 'union' wage. Bonus payments provide another form of flexibility. Besides a change in contracted wages, firms may also respond to a demand shock by varying hours worked and by recruitment and retention decisions.

Given the mixture of national and local bargaining influences on local pay rates, it is clear that there will be more upward flexibility in times of a tight local labour market than downward flexibility in times of a local recession. As Buettner (1999b) notes, when the unconstrained wage that employers would wish to pay is below the wage stipulated by a national collective agreement, the firm becomes constrained and will pay at least the 'contract wage'.

For reasons to be elaborated below, employers who have some control over wages would wish to lower these (or at least limit increases) when the local labour market is slack and unemployment high. Given a mixture of national and local wage setting influences, the responsiveness (elasticity) of wages to the local unemployment rate is likely to be less at high rates of unemployment. This hypothesis was previously empirically confirmed, for example, for the UK and US wage curves by Blanchflower and Oswald (1990) and by Buettner (1999b) for western Germany. The latter found that $\mathrm{d} y / \mathrm{d} u=-0.102 / U$, with $y$ the natural logarithm of average earnings in a region, $u$ the natural logarithm of the unemployment rate and $U$ the percentage unemployment rate. This implies a relatively small unemployment elasticity of pay of between -0.04 at German local unemployment rates of around 2.5 percent to an almost negligible elasticity of -0.005 at unemployment rates of around 18 percent. 
In their 1994 book, Blanchflower and Oswald offer three possible explanations for an inverse relationship between the unemployment rate and local wages. They are: (i) a labour contract model, (ii) an efficiency wage model, and (iii) a bargaining model. A summary and assessment of these alternative models is given by Card (1995).

In the labour contract model, firms and workers agree on a state-contingent wage level and a state-contingent employment level along the lines of the standard Azariadis (1975) and Baily (1974) implicit contracts model. Higher wages will coincide with a higher level of contractual employment. Differences in regional amenities then result in spatial differences in equilibrium wages and employment: regions with attractive amenities have relatively lower wages and higher unemployment rates, while regions with unattractive features offer relatively higher wages and lower unemployment rates.

The labour contract model has been criticised by Card (1995) as being inconsistent with the 'compensating differentials' model in which wage and the unemployment rate are positively related in the long run. Papps (2001), using New Zealand data, shows that the wage curve is not inconsistent with the existence of a long-run spatial equilibrium in which expected wages are equalised across regions and therefore long-run unemployment and long-run wages are positively correlated (see also the classical arguments offered by, e.g., Harris and Todaro, 1970, and Hall, 1972). Instead, the wage curve is likely to be a short-run response of earnings to business cycle variations in labour market tightness.

A union bargaining model can provide a second theoretical explanation for the wage curve. In this model, going back to De Menil (1971), workers in a unionised production sector will extract a wage premium from employers that will be greater in a tighter labour market. Hence an inverse relationship between wages and unemployment rates results. However, for this model to be plausible at the local labour market, collective bargaining must take place at the local level. Buettner and Fitzenberger (2001) provide evidence that the wage curve is less elastic where wages are determined nationally or by industry and more elastic with enterprise-based (i.e. local) bargaining. However, since enterprise-based bargaining between unions and employers is not that common in European countries such as Germany, the union bargaining model would not appear to be the most plausible explanation for the wage curve in the context of the data for western Germany that we use in this paper. 
The third wage curve theory builds on the efficiency wage model of Shapiro and Stiglitz (1984). In their model, it is costly for employers to monitor workers' productivity. In this case, employers will offer a premium on the competitive wage that will discourage workers from shirking. This premium tends to be higher in large enterprises, where monitoring of workers is more costly than in small enterprises (see, e.g., Ringuede, 1998). ${ }^{3}$ Because the expected penalty for shirking, when detected, is greater when it becomes harder to find a job, the threat of unemployment acts as a disciplinary device and firms offer a lower wage premium during times of high unemployment. A wage curve results.

A fourth explanation for the wage curve was put forward by Campbell and Orszag (1998) who modified a model of lump-sum labour turnover costs that is based on Salop (1979) and Phelps (1984). In this model, firms economize on the costs associated with hiring new workers by paying higher wages in order to discourage existing workers from quitting at times of a tight labour market. Again, labour earnings and unemployment rates would have a negative correlation, ceteris paribus.

The above explanations of the wage curve are non-spatial in that they do not explicitly consider the existence of interactions between local labour markets. Hence local labour markets are interpreted as unconnected 'islands' in a national economy. However, if the wage curve is due to individual employers facing upward sloping labour supply curves, any spatial phenomenon that affects the wage elasticity of the labour supply curve will also affect the elasticity of the wage curve. If a region is close to other regions with large labour markets, monopsonistic firms may not be able to respond to a local negative demand shock by lowering the wage, as the threat of unemployment is less when employment opportunities in surrounding regions are plentiful. For example, Burgess and Profit (2001) found empirical evidence of spatial externalities in the British labour market. In particular, high unemployment levels in neighbouring areas tend to raise the number of local vacancies being filled and to lower the local outflow from unemployment.

Buettner (1999a) estimated wage curves and tested specifications with spatially lagged dependent variables, or spatially correlated error terms, by means of

\footnotetext{
${ }^{3}$ There are of course also other reasons why large firms may pay higher wages, for example as a consequence of a positive impact of scale on productivity, or to deter quitting of workers with firmspecific human capital (see, e.g., Coles, 2001, Johansen et al., 2001).
} 
labour market data for 327 regions in western Germany. ${ }^{4}$ Earlier, Blanchflower and Oswald (1994), Wagner (1994) and Baltagi and Blien (1998) had found evidence of a wage curve for Germany using micro data. Nijkamp and Poot (2002) took a sample of 16 estimates from these studies and found that the average unemployment elasticity of pay was about -0.0488 , which is rather less than the average elasticity across a much larger of sample of studies for a wide range of countries, which is about -0.1 . The German elasticity is also smaller than a publication-bias corrected estimate calculated by Nijkamp and Poot (2002), which is about -0.07 . The lower elasticity for Germany is usually explained in terms of the institutional features of the German labour market, with relatively centralised wage bargaining. However, Bellman and Blien (2001) argue that there is more labour market flexibility in Germany at the local level than was previously thought and that, using better data - namely micro data on establishments of firms rather than workers - an elasticity of -0.1 is obtained.

Buettner (1999a) tests spatial dependence in the wage curve regression model by means of Lagrange multiplier (LM) statistics proposed by Anselin et al. (1996). Two types of spatial dependence are usually investigated: first order spatial autoregression (SAR) in the error term and a spatially lagged dependent variable (SLDV). Buettner finds that the null hypothesis of the absence of a spatial lag is rejected, but that there is no evidence of spatial autocorrelation in the errors of the regression model. Interestingly, including a spatial lag of the dependent variable has relatively little impact on the unemployment elasticity of pay.

The presence of a spatial lag is somewhat cumbersome for the estimation of the wage curve, as the OLS estimator in this case is inconsistent. Fairly easily implementable maximum likelihood procedures that can be used with spatial lags in models for cross-sections, as proposed in Anselin (1988), are not appropriate for models with panel data. Techniques for estimation of panel data models with spatial error autocorrelation and a spatially lagged dependent variable are still being developed (Anselin et al., 2003). Estimation is complicated due to the multiple departures from the classical regression model: a choice has to be made between spatial lags in the endogenous variable, or spatially correlated error terms (see also Baltagi et al., 2001, and Elhorst, 2003).

\footnotetext{
${ }^{4}$ Actually, Buettner (1999a) treated two pairs of contiguous regions in Lower Saxony as composite regions and used therefore 325 regions in his regression analysis.
} 
The question also arises as to how to interpret the spatial lag. There could be several reasons for the effect of the spatially weighted wage rates of neighbouring regions on the local wage rate. On the one hand, the higher wage in surrounding regions may increase the opportunity wage of the local worker, thereby raising the local wage that a monopsonistic employer needs to offer in order to attract more workers. Alternatively, the wage in neighbouring areas may be a proxy for spatial spillover effects such as agglomeration advantages, whereby wages and productivity are higher in industry clusters that straddle urbanised regions with high population densities (e.g., Wheaton and Lewis, 2002).

Hence, a more direct approach to test for spatial effect is the use of spatially lagged explanatory variables. Specifically, we will consider the spatially lagged unemployment rate as a regressor in the earnings function. Buettner (1999a) found that inclusion of the spatially lagged unemployment rate lowers the 'own' unemployment elasticity of pay, although the sum of the local and spatial effect of the unemployment rate is greater than the own effect. The latter approach is adopted in the next section and merely requires instrumental variable estimation to generate consistent estimates.

In conclusion, the presence of monopsony in local labour markets suggests a range of hypotheses that will be tested in the subsequent sections. Firstly, if contiguous labour markets are subject to common shocks, wage equations may exhibit spatial residual autocorrelation (SAR).

Secondly, if local pay is affected by employment conditions in neighbouring regions, the spatially lagged wage may be a significant explanatory variable in the wage curve (the spatially lagged dependent variable model). Alternatively, the spatially lagged unemployment rate may be significant (the spatially lagged independent variable model).

Thirdly, the extent of monopsony in the local labour market may be a function of accessibility of this market. Accessibility could affect the local wage level positively (employers must offer higher wages in more accessible regions) and lower the unemployment elasticity of pay (the unemployment elasticity of pay is greater in more isolated regions). We will measure accessibility by means of an index of weighted average distance between the region and the other regions and by means of a measure of spatial interaction. 
Finally, the implications of remoteness can also be tested by splitting the sample of regions into interacting urban agglomerations and relatively isolated rural areas. If monopsony is more prevalent in the latter type of regions, the wage curve will be more elastic in these rural areas. In addition, we would expect that the effect of spatial interaction on wages will be less in a sample of rural regions.

The above hypotheses are tested by means of our panel of wage and labour market variables for the 327 employment regions of the former West Germany (excluding West Berlin) over the period 1990 to 1997. Conventional wage curves are estimated, and compared with earlier findings, in the next section. Section 4 tests a range of spatial effects.

\section{Another look at the wage curve in Germany}

In this section we present estimates of a conventional wage curve using a data set provided by the German Institute for Employment Research (IAB Institut für Arbeitsmarkt und Berufsforschung), containing data on full time workers employed in western Germany. The data, which are only available in aggregated form at the spatial level of 327 regions, contain information about average daily wages and the average unemployment rate in each region. Information about the number of persons employed subdivided by gender, size of firm, industry and level of education is available as well. $^{5}$

Figure 1 shows the spatial variation of the unemployment rate across West German regions, in 1997. The spatial pattern suggests the presence of a positive correlation of unemployment rates among neighbouring regions. The unemployment rate seems to be generally lower in the south than in north. The highest levels of unemployment are in those northern regions bordering those belonging to the former East Germany.

Figure 1 about here

The presence and effect of such spatial patterns in unemployment rates and their impact on wage levels will be investigated further in the next section of this

\footnotetext{
${ }^{5}$ More detailed information on the data set can be found in the Annex.
} 
paper. We first re-estimate conventional German wage curves with our available regional data.

Using a panel on the average wage in each of the regions, there are two ways to control for composition effects. First, an expected regional wage can be computed that applies the national wage for each group to the local composition of employment across groups. The expected wage is then included as an additional regressor in the wage equation. Buettner (1999a) adopted this approach and consistently found that this regressor had a coefficient of close to one. The alternative is to control for composition effects by inserting composition variables on the right hand side of the earnings equation. In the absence of appropriately disaggregated national wage data that matched our regional data, this is the only option available with the present data and this method has therefore been adopted in the research reported in this paper. Our estimation of the wage curve is therefore based on the following specification:

$$
y_{j t}=\alpha+\beta u_{j t}+\gamma\left(u_{j t}\right)^{2}+\mathbf{x}_{j t}{ }^{\prime} \delta+\left(d_{j}+f_{t}+\varepsilon_{j t}\right)
$$

where $y_{j t}$ is the natural logarithm of the average wage in region $j$ at time $t, u_{j t}$ is the natural logarithm of the unemployment rate in region $j$ at time $t$ and $\left(u_{j t}\right)^{2}$ is its square. The terms $d_{j}$ and $f_{t}$ are fixed effects over regions and time respectively while $\varepsilon_{j t}$ is the stochastic disturbance term. Finally, the term $\mathbf{x}_{j t}$ contains information about regional employment characteristics obtained using four different ways of grouping the number of employees.

Wages of female workers are found to be less responsive to the local unemployment rate than wages of male workers in many wage curve estimations (Baltagi and Blien, 1998, provide evidence for western Germany). This result is usually explained by the higher elasticity of women's labour supply curve. ${ }^{6}$ An aggregate analysis neglecting the possible existence of gender-specific wage curves would probably underestimate the unemployment elasticity of pay for men in western Germany. Unfortunately, the data available for our analysis are too aggregated to allow us to estimate wage curves separately for men and women. Instead, the share of

\footnotetext{
${ }^{6}$ See, for example, Killingsworth (1983). The greater supply elasticity of women reduces the potential for monopsonistic wage setting by local employers. However, the lower female elasticity is not entirely undisputed. Baltagi et al. (2000) and Kennedy and Borland (2000) find that the wage curve elasticity of women is greater than that of men, using data on East Germany and Australia respectively.
} 
women in region $j$ at time $t$ provides a level effect on wages by gender that is the first control variable included in the vector $\mathbf{x}_{j t}$.

Secondly, as noted in the previous section, small firms have less monitoring costs and offer different employment opportunities than large firms; leading to the latter usually paying higher wages (e.g., Ringuede, 1998). The proportion of small firms established in a particular region may consequently have an influence on local wages. For these reasons the second control variable included in the row vector $\mathbf{x}_{j t}$ is the share of workers employed in small firms with less than 20 employees in region $j$ at time $t$.

Furthermore, since Mincer's classic contribution on the determinants of earnings (Mincer, 1974), it is well known that education is a prime determinant of earnings. Given our use of aggregate data we would expect education to exert a composition effect: the average wage will be lower in regions with a relatively less educated work force. On the basis of these considerations, the third control variable we include in the vector $\mathbf{x}_{j t}$ is the share of less educated workers in region $j$ and time $t$.

Finally, wages may differ substantially across sectors. Furthermore, we may expect rural regions to have on average wages that are lower than in urbanized regions due to agglomeration advantages of the latter and the associated productivity gains (e.g., Fujita and Thisse, 2002). Since we may identify rural areas as those regions in which the percentage of people employed in agriculture is relatively high, the fourth control variable we include in the vector $\mathbf{x}_{j t}$ is the share of workers employed in agriculture in region $j$ and time $t$.

Given the above-mentioned data framework and data, we first estimated a conventional wage curve using a standard OLS-FE (Ordinary Least Squares, Fixed Effect) approach. ${ }^{7}$ The results of this estimation are shown in the first two columns of Table 1.

Table 1 about here

The estimates in Table 1 allow for a varying elasticity. Comparing columns (1) and (2), the logarithm of the unemployment rate performs clearly better than the

\footnotetext{
${ }^{7}$ These estimations have been carried out using Stata 7 (updated version).
} 
reciprocal of the unemployment rate. The elasticity at the mean unemployment rate of 7.64 percent is -0.02 based on column (1), and the elasticity is declining at greater unemployment rates, as expected. The elasticity is rather smaller than in earlier research on western Germany, to which the aggregated nature of the data and the limited range of controls undoubtedly contributed. Nonetheless, the wage curve is statistically significant and the data do permit identification of spatial effects, as will be shown below.

Given that the data are aggregated to the regional level, the logarithm of the unemployment rate is likely to be an endogenous regressor. The Hausman test performed on the specification of column (1) in Table 1 gives a value of 14.32, which is significant at the 1 percent level. Given the endogeneity of unemployment, we conclude that a two-stage least squares (2SLS) estimator is required. For this reason we applied a 2SLS estimation approach with fixed effects (2SLS-FE), with the results shown in the last two columns of Table 1. The instruments used for the 2SLS estimation are the exogenous variables and the logarithm of the unemployment rate with a one-year lag. Consequently, seven years of observations were available (199197).

Again the unemployment rate in reciprocal form is not statistically significant, but the wage curve is present when using the logarithm of the unemployment rate and its square as regressors. At the mean unemployment rate, the unemployment elasticity of pay is now -0.01, and further declining at higher unemployment rates, as expected. The control variables are statistically significant in all specifications and show the expected signs, except for the share of less educated workers in some cases.

Given the panel nature of the data, a choice must be made between a fixed effects or a random effects specification. The test statistic suggested by Keane and Runkle (1992) and by Baltagi (2001) to compare the fixed effects model with the first difference estimator has a value of 4.5680 , which is not significant at conventional levels (the test statistic has a chi-square distribution with 11 degrees of freedom). Consequently, the usual Hausman test to compare the fixed and random effect estimators is the appropriate one. The latter test, with a value of 91.57 , rejects the random effects model in favour of the fixed effects one. ${ }^{8}$ Consequently, the 2SLS-FE model of column (3) forms the benchmark for further analysis.

\footnotetext{
${ }^{8}$ These values refer to the log-linear specification of the model given in Table 1, column 3 .
} 


\section{Testing for spatial effects}

The geographical unit we use in this analysis generally covers a small geographical area that in many cases may not exactly coincide with a well-defined local labour market area. Consequently, we may expect a high number of commuters between neighbouring regions, which may be one cause of regional spatial dependence. In order to verify the existence of spatial dependence we computed the Moran's I statistic and a Lagrange Multiplier $(L M)$ test statistic on the variables of interest (wages and unemployment) as proposed by Anselin $(1988,2001) .{ }^{9}$ This requires the construction of a spatial weight matrix. Each element of the spatial weight matrix is proportional to the inverse of the Euclidean distance between the locations of the corresponding regional authorities of contiguous regions. Following Buettner (1999b), distances between non-contiguous regions are assumed to be infinite and the correspondent elements of the spatial weight matrix are therefore zero. This is not a highly restrictive assumption. Analogous to the case of the maximum lag length in temporal autocorrelation, some cut-off has to be assumed. The hybrid weight matrix here is a good compromise between a Boolean (zero-one) weight matrix based on contiguity and a full distance matrix. ${ }^{10}$ Finally, the elements of the spatial weight matrix were row standardized, that is, the elements of each row add to unity.

The results are reported in Table 2. While the distribution of Moran's I statistic depends on the assumptions regarding the data generating process, spatial autocorrelation is clearly present in our data. This is confirmed by the $L M$ statistic, which is asymptotically distributed as $\chi^{2}$ with one degree of freedom. It can be seen from Table 2 that spatial correlation in wages and unemployment rates across the employment regions of western Germany exhibits a slightly downward trend during the 1990s. Also, the spatial correlation is much stronger for unemployment rates than for wages.

\footnotetext{
${ }^{9}$ The $L M$ test statistic has a simple functional relationship with Moran's (1948) I statistic, as noted by Anselin (1988, p.191). See also Table 2. Moran's I was computed by means of Spacestat version 1.91.

${ }^{10}$ A full distance matrix is usually not ideal because positive dependence for regions that are close in space averages out with negative dependence (e.g. based on some sort of hierarchical pattern) with regions further away. Moreover, simulation experiments have shown that the power of tests such as Moran's $I$ is generally higher for relatively sparse weight matrices. We are grateful to Raymond Florax for pointing this out to us.
} 
Table 2 about here

Figure 2 and Figure 3, reporting the Moran scatterplot of the logarithms of the regional average wages and unemployment rate respectively, in 1990 and 1997 further corroborate the results of Table 2. The relationship between the log unemployment rate and its spatial lag has become weaker from 1990 to 1997, though in both cases it is stronger than the relationship between the log wage and its spatial lag. These results suggest that regions with high (low) unemployment rates or wages are generally located close to other regions with high (low) unemployment rates or wages respectively.

Figures 2 and 3 about here

In what follows we take account of the panel nature of the data and allow for contemporaneous spatial correlation, but assume an absence of direct intertemporal spatial dependence. That is, we construct an $N(T-1) \times N(T-1)$ block diagonal spatial weight matrix, in which the sub matrices on the main diagonal are each equal to the above-defined $N \times N$ row standardized spatial weight matrix. ${ }^{11}$

The $L M$ test statistic for spatial correlation in the error term computed from the model of column (3) in Table 1 is 5.8937 (the average over time of the crosssectional $L M$ statistics), which is significant at the 5 percent level, but not at the 1 percent level. The spatial correlation in the error component suggests the presence of some relationship between regions that is not accounted for in this model. The specification of the wage curve in Table 1 only relates the local wage to the local unemployment rate and neglects the geographical location of regions as well as the existence of spatial contiguity effects and spillovers between regions. Instead, we would expect the relationship between local wages and the local unemployment rate to differ depending on employment opportunities in the surrounding areas and on the relative cost of commuting or migrating. We can take account of the spatial structure in the wage curve estimation in different ways, summarized in the following model:

\footnotetext{
${ }^{11}$ The number of time periods is T-1 because one year is lost by using the lagged natural logarithm of the unemployment rate as an instrument in 2SLS least squares estimation.
} 


$$
\begin{gathered}
y_{j t}=\alpha+\beta u_{j t}+\gamma\left(u_{j t}\right)^{2}+\lambda_{1} \sum_{i} u_{i t} w_{j i}+\lambda_{2}\left(\sum_{i} u_{i t} w_{j i}\right) u_{j t}+ \\
\rho_{1} S S E_{j t}+\rho_{2} S S E_{j t} u_{j t}+\mathbf{x}_{j t}{ }^{\prime} \delta+\left(d_{j}+f_{t}+\varepsilon_{j t}\right)
\end{gathered}
$$

where $w_{j i}$ is the element of the $j^{\text {th }}$ row and $i^{\text {th }}$ column of the above mentioned spatial weight matrix. The term $\Sigma_{i} u_{i t} w_{j i}$ is therefore a weighted average of the natural logarithm of the unemployment rate in neighbouring regions. This term, which we refer to as spatial lag of the unemployment rate, captures the responsiveness of regional wages to the unemployment rate of the surrounding regions. The interaction between the spatial lag of the explanatory variable and the log of the unemployment rate should capture the additional downward pressure on wages that we expect to find in regions that have growing unemployment and are surrounded by other regions with high unemployment rate.

The spatial spillover effect term $S S E_{j t}$ reflects the impact of regional agglomeration and accessibility on wages. We compute $S S E_{j t}$ in two different ways. Firstly, the easiest way to compute the agglomeration index is to add the inverse of the distances between a region and its neighbours, weighted by employment in these regions. Hence

$$
A_{j t}=\sum_{i} E_{i t} w_{j i}
$$

where $E_{i t}$ represents the number of people employed in region $i$ at time $t$.

A second way to capture regional spillover effects consists of computing a measure of spatial interaction based on the number of people employed in each contiguous region. We then compute a spatial interaction indicator $\left(T_{i j t}\right)$ in the following way:

$$
T_{i j t}=\psi\left(E_{i t}{ }^{\tau} E_{j t}{ }^{v} w_{j i}\right)
$$

We will assume $\tau=v=0.5$ which are common choices in gravity models of spatial interaction (see, e.g., Sen and Smith, 1995) and $\psi=1$ without loss of generality. 
Finally, we computed the sum over $i$ of $T_{i j t}$, obtaining the index we used in our regression models:

$$
T_{j t}=\sum_{i} T_{i j t}=\sum_{i}\left(E_{i t} E_{j t}\right)^{0.5} w_{j i}
$$

In both cases, $A_{j t}$ or $T_{j t}$, our hypothesis is that the spatial spillover effect on wages is positive. In addition, the interaction between the two measures of $S S E_{j t}$ and the $\log$ of the unemployment rate is expected to have a positive coefficient, as the unemployment elasticity of pay is expected to be less in the more agglomerated and less remote regions.

The results of the estimation of the various specifications of equation (2) are shown in Table 3.

Table 3 about here

In the first two columns of Table 3 we add the $S S E_{j t}$ indicator as defined in equation (3) and (5) respectively, and its interaction with the unemployment rate. The two models give similar results. In both cases the level effect $\left(A_{j t}\right.$ and $\left.T_{j t}\right)$ is positive and highly significant. This result implies that wages in more agglomerated and accessible regions are higher, ceteris paribus. Between the first two models of Table 3, the one in which the agglomeration/accessibility index is measured by $T_{j t}$ gives the better fit.

As before, the unemployment elasticity of pay can be computed to be negative at the mean and the elasticity is again less at higher rates of unemployment. In addition, the coefficient of the interaction between the agglomeration/accessibility measure and the logarithm of the unemployment rate is significant and positive. The wage curve is therefore less elastic in those regions that are located close to highly agglomerated or highly accessible areas. This finding is consistent with the idea that employers are less likely to lower wages in response to an increase in the local unemployment rate if they fear that their workers will quit their current jobs for similar ones in a neighbouring region. ${ }^{12}$

\footnotetext{
${ }^{12}$ The question naturally arises whether the accessibility variable $A_{j t}$ and the spatial interaction variable $T_{j t}$ are exogenous regressors. Endogeneity tests suggested that they generally are. For example, the endogeneity test of $T_{j t}$ in the model of Table 3 column (3) yields a value of 5.72, which is not significant at the 1 percent level of corresponding $\mathrm{F}(1,1950)$ distribution. In any case, the coefficients
} 
The LM test for spatial correlation of the residuals computed on these two models is significant at the 5 percent level, although less so than the value obtained for models in which no spatial spillovers are taken into account. To capture residual spatial autocorrelation, we add the spatially weighted unemployment rate and its interaction with the local unemployment rate to the model of column (2). The results are reported in column (3).

Both the spatially lagged unemployment rate and its interaction with the local unemployment rate are statistically significant. It can be easily calculated that, taking the interaction effect into account, the elasticity of wages with respect to the unemployment rate is -0.001 , i.e. negative but very small. It is indeed plausible that wages respond less to a change in the spatially lagged unemployment rate than in a change in the local unemployment rate. Moreover, the negative response of wages to unemployment in surrounding regions is greater when the local unemployment rate is higher (the coefficient of the interaction term is negative). This is also consistent with the models of monopsonistic local labour markets discussed in Section 2. One possible explanation of the negative interaction term is the fact that the chances are lower that workers might find alternative jobs in neighbouring regions when unemployment in neighbouring regions is higher. This puts downward pressure on wages in the local labour market.

The LM test for residual spatial autocorrelation on the third model of Table 3 is not significant at conventional levels. The spatial lag of the unemployment rate is therefore a variable which is able to pick up the regional spatial spillovers in our data. For this reason it is not necessary to consider additional specifications that include lags of the dependent variable or spatial lags in the error term. Although now common for cross section data, such spatial models are not yet standard practice and easily implemented in case of panel data. Furthermore, in countries such as Germany where collective wage agreements play an important role, the economic interpretation of the spatial lag of the unemployment rate is more satisfactory than that of a spatial lag of wages.

In addition to spatial dependence, two other issues that are of interest are those of spatial non-stationarity and specific forms of spatial heterogeneity. We consider 
these two in turn. First, we test for spatial stationarity of all coefficients of interest using the procedures for geographically weighted regression (GWR) suggested by Fotheringham et al. (1998). ${ }^{13}$ The results of such a test, computed for each year separately in order to exclude the potential impact of temporal non-stationarity, are shown in Table 4.

Table 4 about here

The nonstationarity test is significant for the log unemployment rate and its square both in 1991 and in 1997, while the coefficients of the other explanatory variables are generally stationary over space. ${ }^{14}$ These results support our idea that the wage curve relationship is strongly location dependent.

The cause of spatial non-stationarity may be a specific form of spatial heterogeneity in the data. It is likely that not all local labour markets are equally strongly influenced by surrounding labour markets. While highly accessible regions metropolitan areas for example - may show a high level of spillover to the surrounding area, less accessible regions - rural areas - may have only weak relationships and generate only small spillover effects to contiguous regions. We may then expect the relationship between local wages and the local unemployment rate to be stronger in rural than in urban areas.

In order to test whether the relationship between local wages and the local unemployment rate is stronger in rural than in urban areas, we adopt the IAB classification of regions in more and less urbanised ones. Specifically, we divide our regions in three groups: regions with high, weak and no agglomeration. This classification is computed on the basis of the density of the population and on the basis of the centrality of the location of each region, according to the definition by

\footnotetext{
${ }^{13}$ The estimation was done with the GWR routine of Stata 7. The spatial weighting function was Gaussian and all observation were included in the computation of the weighted regressions. Monte Carlo simulations (which compare the observed coefficients with the one obtained from randomly rearranging the data in space and then repeating the GWR procedure) involved 1000 replications. Since consistent estimates were obtained with 2SLS, the GWRs were computed on the second stage regression (after predicting the log unemployment rate).

${ }^{14}$ With discrete disaggregation of the data into regions with strong agglomeration, weak agglomeration and no agglomeration, the coefficients of the spatial interaction term $T_{j t}$ and its interaction with the local unemployment rate are also significantly different between the three types of regions (see Table 5). However, such results are not directly comparable with those of GWR.
} 
Bellman and Blien (2001). Details can be found in the Annex. The group of regions with high agglomeration comprises 118 of the 327 regions used in the previous analysis, while the group with no agglomeration consists of 90 regions. The remaining group (regions with weak agglomeration), which can be considered as a hybrid group, comprises the remaining 119 regions.

In Table 5 we show separate wage curve regressions for the three groups, and obtain noticeably different results. In the first three columns of Table 5 we estimate the model without any spatial regressors - equivalent to column (2) of Table 3 - while in the fourth, fifth and sixth column we estimate the model with the spatial lag of the $\log$ unemployment rate included. Both kinds of models lead to similar conclusions, which is plausible given that, firstly, the LM statistic of spatially correlated errors of the first group of models is only slightly significant and, secondly, that the spatial lag in the second group of models is itself insignificant.

\section{Table 5 about here}

Table 5 shows that the coefficient of the log unemployment rate is negative and significant in regions with no agglomeration, while the interaction between the $\log$ unemployment rate and the spatial interaction index $T_{j t}$ is not significant. This suggests that there are few wage spillover effects between these regions and surrounding regions.

In regions with strong agglomeration, however, we find no evidence of a wage curve: the coefficient of $\log$ unemployment rate is not significantly different from zero. However, the spatial interaction effect is now significant at the 1 percent level and positive, confirming the importance of spillover effects. These results are consistent with the idea that employers in such urban regions face competition of the surrounding labour markets and with the presence of agglomeration effects among these types of regions.

Finally, the results of Table 5 suggest that the statistical significance and magnitude of the unemployment elasticity of pay is related to the scale of the geographic disaggregation. As Fischer and Nijkamp (1987) argued, a 'labour market area' is a region within which there is a clear labour market pattern defined by the spatial range of employment opportunities open to a worker without changing his place of residence (p. 3). If the spatial unit of observation would be a 'true' local 
labour market area defined by a virtual absence of cross-border commuting and cost cross-border migration, we would expect a wage curve to be present, whereas in the case of more ambiguous local labour market borders the wage curve may be less easy to identify.

\section{Conclusions}

In this paper, we explored the role of spatial effects and of spatial heterogeneity in wage curve estimation by means of data on regions of western Germany. The results reconfirm the presence of a wage curve, but also confirm that spatial effects matter. Taking monopsony as being one of the main causes of the wage curve, we test whether the wage curve is more elastic in more isolated regions and the results confirm this hypothesis. Clearly, monopsony is explained in our research by the potential threat of a move of workers to adjacent areas that will require the worker to accept a larger commuting distance, or to migrate. The lower the cost, the more elastic local labour supply is expected to be and therefore the lower the opportunity for monopsonistic exploitation. This phenomenon would warrant further investigation (see also van Ommeren and Rietveld, 2002, on the related issue of endogenous commuting costs).

Wages are also higher in strongly interacting regions. While this is consistent with the conclusions of efficiency wage or labour turnover cost models, there may also be other causes, such as agglomeration effects. The available data do not permit us to identify the role of local monopsony vis a vis other causes of spatial variation in the wage curve.

In general, we expect that local monopsony is widespread, but that the resulting allocative inefficiency is probably only small (see also Boal and Ransom, 1997). Nonetheless, the phenomenon is particularly of interest in terms of variations between firms and workers at the micro level: it allows us to identify those types of firms for whom 'lump sum costs' such as training and recruitment cost matter and workers for whom migration and commuting costs matter. Moreover, the way in which such firms and workers are allocated across regions is also of interest and will have an impact on the estimation of the wage curve.

Hence, effects of monopsony may be stronger for some groups of workers than for others. Card (1995, p. 793) noted for example that wage curves may be less elastic for more senior workers and better educated workers. Differences in the 
migration propensities across groups of workers and differences in their spatial dispersion could contribute to the urban-rural wage curve dichotomy identified in this paper. The testing of spatial effects in wage curves for specific groups of workers remains a task for a future paper.

\section{References}

Anselin, L. (1988) Spatial Econometrics: Methods and Models. Kluwer Academic Publishers.

Anselin, L. (2001) Spatial Econometrics, in A Companion to Theoretical Econometrics, ed. by B. H. Baltagi: Blackwell Publishers, Massachusetts, 310-330.

Anselin, L., Bera, A.K., Florax, R. and Yoon, M.J. (1996) "Simple diagnostic tests for spatial dependence", Regional Science and Urban Economics 26: 77-104.

Anselin, L., Florax, R. J. G. M. and Rey, S. (2003) Econometrics for Spatial Models: Recent Advances, in Advances in Spatial Econometrics: Methodology, Tools and Application, ed. by L. Anselin, R. J. G. M. Florax and S. Rey: Springer-Verlag, 1-36.

Azariadis, C. (1975) "Implicit contracts and underemployment equilibria", Journal of Political Economy 83: 1183-202.

Baily, M.N. (1974) "Wages and employment under uncertain demand", Review of Economic Studies 41: 37-50.

Baltagi, B.H. (2001) Econometric Analysis of Panel Data, Wiley \& Sons.

Baltagi, B. H. and Blien, U. (1998) "The German wage curve: evidence from the IAB employment sample", Economics Letters, 61: 135-42.

Baltagi, B. H., Blien U., Wolf K. (2000) “The East German wage curve 1993-1998”, Economics Letters, 69: 25-31.

Baltagi, B.H., Song, S.-H. and Koh, W. (2001) "Testing panel data regression models with spatial error correlation", Working Paper, Department of Statistics, Korea University.

Bellmann, L. and Blien U. (2001) "Wage curve analyses of establishment data from western Germany", Industrial and Labor Relations Review 54: 851-863.

Bhaskar, V. and To, T. (1999) "Minimum wages for Ronald McDonald monopsonies: a theory of monopsonistic competition", Economic Journal 109: 190-203.

Blackaby, D.H. and Hunt, L.C. (1992) "The 'wage curve' and long-term unemployment: a cautionary note”, The Manchester School 60: 419-28.

Blanchflower, D. and Oswald, A. (1990) "The wage curve", Scandinavian Journal of Economics 92: 215-37.

Blanchflower, D. and Oswald, A. (1994) The Wage Curve, MIT Press.

Boal, W.M. and Ransom, M.R. (1997) "Monopsony in the labor market", Journal of Economic Literature 35(1): 86-112.

Boushey, H. (2002) "Reworking the wage curve: exploring the consistency of the model across time, space and demographic group", Review of Political Economy 14: 293-311.

Bratsberg, B. and Turunen, J. (1996) "Wage curve evidence from panel data", Economics Letters 51: 345-53.

Buettner, T. (1999a) "The effect of unemployment, aggregate wages, and spatial contiguity on local wages: An investigation with German region level data", Papers in Regional Science 78: 47-68.

Buettner, T. (1999b) Agglomeration, Growth, and Adjustment: A Theoretical and Empirical Study of Regional Labor Markets in Germany, Springer-Verlag.

Buettner, T. and Fitzenberger, B. (2001) "Central wage bargaining and wage flexibility: evidence from the entire wage distribution”, mimeo, Mannheim University, Germany.

Burgess, S. and Profit, S. (2001) "Externalities in the matching of workers and firms in Britain", Labour Economics 8: 313-33.

Campbell, C. and Orszag, J.M. (1998) “A model of the wage curve”, Economics Letters 59: 119-25.

Card, D. (1995) "The Wage Curve: A Review”, Journal of Economic Literature 33: 785-99.

Coles, M.G. (2001) "Equilibrium wage dispersion, firm size, and growth", Review of Economic Dynamics 4: 159-87.

De Menil, G. (1971) Bargaining: Monopoly Power Versus Union Power, MIT Press. 
Dohse, D., Krieger-Boden, C. and Soltwedel, R. (2002) "EMU and regional labor market disparities in Euroland", in: Cuadrado-Roura, J.R. and Parellada, M. (eds.) Regional Convergence in the European Union, Springer-Verlag, pp. 339-352.

Elhorst, J. P. (2003) Specification and Estimation of Spatial Panel Data Models, International Regional Science Review, 26 (3) 244-268.

Fischer M. M. and Nijkamp P. (1987) 'Spatial Labour Markets Analysis: Relevance and Scope', in: Fischer M. M. and Nijkamp P. (eds.) Regional Labour Markets, North Holland, pp. 1-33.

Freeman, R.B. (1998) "War of the models: which labour market institutions for the $21^{\text {st }}$ century", Labour Economics 5: 1-24.

Fotheringham, A.S., Charlton, M.E. and Brunsdon C. (1998) Geographically weighted regression: a natural evolution of the expansion method for spatial data analysis, Environment and Planning $A$ 30: 1905-27.

Fujita, M. and Thisse, J.-F. (2002) Economics of Agglomeration, Cambridge University Press.

Gorter, C. and Poot, J. (1999) "Measuring the impact of labour market deregulation", in: Crampton, G. (ed.) Research in Labour Economics. Advances in European Research in Regional Science, Volume 9, Pion, pp. 63-90.

Hall, R.E. (1972) “Turnover in the labour force”, Brookings Papers on Economic Activity 3: 369-402.

Harris, J.R. and Todaro, M.P. (1970) "Migration, unemployment and development: a two sector analysis", American Economic Review 60: 126-42.

Ikkaracan, I. and Selim, R. (2003) "The role of unemployment in wage determination: further evidence on the wage curve from Turkey", Applied Economics 35: 1589-1598.

Janssens, S. and Konings, J. (1998) "One more wage curve: the case of Belgium”, Economics Letters 60: $223-27$.

Johansen, K., Ringdal, K. and Thoring, T.A. (2001) "Firm profitability, regional unemployment and human capital in wage determination", Applied Economics 33: 113-21.

Karagedikli, Ö, Maré, D. and Poot, J. (2000) "Disparities and despair: changes in regional income distributions in New Zealand 1981-1996", Australasian Journal of Regional Studies 6: 323-47.

Keane, M.P. and Runkle, D.E. (1992) "On the estimation of panel-data models with serial correlation when instruments are not strictly exogenous", Journal of Business and Economic Statistics 10: 1-9.

Kennedy, S. and Borland, J. (2000) “A wage curve for Australia?”, Oxford Economic Papers 52: 774803.

Killingsworth, M.R. (1983) Labour Supply, Cambridge University Press.

Manning, A. (2003) Monopsony in Motion: Imperfect Competition in Labor Markets. Princeton University Press.

Mincer, J. (1974) Schooling, experience and earnings, Columbia University Press.

Molho, I. (1992) "Local pay determination”, Journal of Economic Surveys 6: 155-94.

Moran, P. (1948) "The interpretation on statistical maps", Journal of the Royal Statistical Society B 10: 243-51.

Morrison, P.S., Papps, K.L. and Poot, J. (2003) "Wages, employment, labour turnover and the accessibility of local labour markets", School of Economics and Finance, Victoria University of Wellington.

Montuenga, V., Garcia, I. and Fernandez, M. (2003) "Wage flexibility: evidence from five EU countries based on the wage curve", Economics Letters 78: 169-174.

Nijkamp, P. and Poot, J. (2002) “The last word on the wage curve?", Discussion Paper 02-029/3, Tinbergen Institute, Amsterdam.

Papps, K. (2001) Investigating a wage curve for New Zealand”, New Zealand Economic Papers 35 : 218-39.

Phelps, E. (1984) Structural Slumps: the Modern Equilibrium Theory of Unemployment, Interest and Assets, Harvard University Press.

Rama, M. and Scott, K. (1999) "Labor earnings in one-company towns: theory and evidence from Kazakhstan”, World Bank Economic Review 13: 185-209.

Ringuede S. (1998) “An efficiency wage model for small firms: firm size and wages”, Economics Letters 59: 263-68.

Salop, S. (1979) "A model of the natural rate of unemployment", American Economic Review 69: 11725.

Sato, Y. (2000) "Search theory and the wage curve", Economics Letters 66: 93-8.

Sen, A. and Smith, T.E. (1995) Gravity Models of Spatial Interaction Behavior, Springer Verlag.

Shapiro, C. and Stiglitz, J.E. (1984) "Equilibrium unemployment as a worker discipline device", American Economic Review 74: 433-44. 
van Ommeren, J. and Rietveld, P. (2002) "Commuting, spatial search and labour market bargaining', Discussion Paper 02-039/3, Tinbergen Institute, Amsterdam.

Wagner, J. (1994) “German wage curves, 1979-90", Economics Letters, 44: 307-11.

Wheaton, W.C. and Lewis, M.J. (2002) 'Urban wages and labor market agglomeration', Journal of Urban Economics 51: 542-62.

Winter-Ebmer, R. (1996) "Wage curve, unemployment duration and compensating differentials", Labour Economics 3: 425-34. 
Table 1: Replication of the wage curve for western Germany

\begin{tabular}{|c|c|c|c|c|}
\hline Dependent Variable: ln wage & $\begin{array}{c}(1) \\
\text { OLS-FE }\end{array}$ & $\begin{array}{c}(2) \\
\text { OLS-FE }\end{array}$ & $\begin{array}{c}(3) \\
\text { 2SLS-FE }\end{array}$ & $\begin{array}{c}(4) \\
\text { 2SLS-FE }\end{array}$ \\
\hline ln unemployment & $\begin{array}{c}0.0184 * \\
(0.0096)\end{array}$ & & $\begin{array}{r}-0.0503 * * * \\
(0.0189)\end{array}$ & \\
\hline$(\text { ln unemployment })^{2}$ & $\begin{array}{r}-0.0095 * * * \\
(0.0030)\end{array}$ & & $\begin{array}{c}0.0101^{*} \\
(0.0055)\end{array}$ & \\
\hline $1 /$ unemployment rate & & $\begin{array}{r}0.0068 \\
(0.0541)\end{array}$ & & $\begin{array}{r}0.1902 \\
(0.1266)\end{array}$ \\
\hline$(1 / \text { unemployment rate })^{2}$ & & $\begin{array}{r}0.0133 \\
(0.0872)\end{array}$ & & $\begin{array}{r}-0.2587 \\
(0.1908)\end{array}$ \\
\hline Share of women & $\begin{array}{r}-0.7721 * * * \\
(0.0833)\end{array}$ & $\begin{array}{r}-0.8214 * * * \\
(0.0827)\end{array}$ & $\begin{array}{r}-1.0583 * * * \\
(0.1013)\end{array}$ & $\begin{array}{r}-0.9301 * * * \\
(0.0840)\end{array}$ \\
\hline Share of small firms & $\begin{array}{r}-0.3606 * * * \\
(0.0630)\end{array}$ & $\begin{array}{r}-0.3967 * * * \\
(0.0630)\end{array}$ & $\begin{array}{r}-0.2458 * * * \\
(0.0627)\end{array}$ & $\begin{array}{r}-0.2535 * * * \\
(0.0672)\end{array}$ \\
\hline Share of less educated workers & $\begin{array}{r}-0.0398 \\
(0.1003)\end{array}$ & $\begin{array}{r}-0.0178 \\
(0.1005)\end{array}$ & $\begin{array}{r}-0.2148 * * \\
(0.0999)\end{array}$ & $\begin{array}{r}-0.2120 * * \\
(0.0986)\end{array}$ \\
\hline Share of employed in agriculture & $\begin{array}{r}-0.4426 \\
(0.2969)\end{array}$ & $\begin{array}{r}-0.5910 * * \\
(0.2963)\end{array}$ & $\begin{array}{r}-0.8029 * * * \\
(0.3091)\end{array}$ & $\begin{array}{r}-0.6159 * * \\
(0.2985)\end{array}$ \\
\hline Constant & $\begin{array}{r}4.9300^{* * *} \\
(0.1054)\end{array}$ & $\begin{array}{r}4.9420 * * * \\
(0.1047)\end{array}$ & $\begin{array}{r}5.2565^{* * *} \\
(0.1087)\end{array}$ & $\begin{array}{r}5.1207 * * * \\
(0.1037)\end{array}$ \\
\hline Observations & 2616 & 2616 & 2289 & 2289 \\
\hline $\mathrm{Nr}$ of regions & 327 & 327 & 327 & 327 \\
\hline $\begin{array}{l}R^{2} \text { within }(\#) \\
R^{2} \text { between }\end{array}$ & $\begin{array}{l}0.6507 \\
0.5414\end{array}$ & $\begin{array}{l}0.6487 \\
0.5349\end{array}$ & $\begin{array}{l}0.5961 \\
0.5356\end{array}$ & $\begin{array}{l}0.6012 \\
0.5594\end{array}$ \\
\hline
\end{tabular}

Standard errors in parentheses

* Significant at $10 \%$; * significant at $5 \%$; *** significant at $1 \%$

All models include time dummies

(\#) Pseudo- $R^{2}$ for the 2 SLS estimations 
Table 2: Spatial autocorrelation in wages and unemployment across regions of western Germany

\begin{tabular}{|c|c|c|c|c|}
\hline \multirow[t]{2}{*}{ Year } & \multicolumn{2}{|c|}{ ln wage } & \multicolumn{2}{|c|}{ In Unemployment Rate } \\
\hline & Moran's I & $L M^{\mathrm{b}}$ & Moran's $I^{\mathrm{a}}$ & $L M^{\mathrm{b}}$ \\
\hline 1990 & 0.466 & 143.49 & 0.746 & 367.72 \\
\hline 1991 & 0.449 & 133.21 & 0.720 & 342.53 \\
\hline 1992 & 0.442 & 129.09 & 0.670 & 296.61 \\
\hline 1993 & 0.457 & 138.00 & 0.620 & 253.99 \\
\hline 1994 & 0.456 & 137.39 & 0.601 & 238.66 \\
\hline 1995 & 0.454 & 136.19 & 0.614 & 249.10 \\
\hline 1996 & 0.479 & 151.60 & 0.603 & 240.26 \\
\hline 1997 & 0.416 & 114.35 & 0.560 & 207.21 \\
\hline
\end{tabular}

a Moran's $I=\frac{(\mathbf{x}-\mu)^{\prime} \mathbf{W}(\mathbf{x}-\mu)}{(\mathbf{x}-\mu)^{\prime}(\mathbf{x}-\mu)}$ with $\mathbf{W}$ the row-standardized spatial weight matrix and $\mu$ is the mean of the spatial vector $\mathbf{x}$.

b The Lagrange Multiplier statistics is $\mathrm{LM}=\frac{(N I)^{2}}{C}$ with $C=\operatorname{tr}\left(\mathbf{W}^{\prime} \mathbf{W}+\mathbf{W}^{2}\right)$. This statistic is asymptotically distributed as $\chi^{2}$ with one degree of freedom. 
Table 3: Testing for spatial spillovers

\begin{tabular}{|c|c|c|c|}
\hline Dependent Variable: ln wage & $\begin{array}{c}(1) \\
\text { 2SLS-FE }\end{array}$ & $\begin{array}{c}(2) \\
\text { 2SLS-FE }\end{array}$ & $\begin{array}{c}(3) \\
\text { 2SLS-FE }\end{array}$ \\
\hline In unemployment rate & $\begin{array}{l}-0.0583 * * * \\
(0.0216)\end{array}$ & $\begin{array}{c}-0.0563 * * * \\
(0.0214)\end{array}$ & $\begin{array}{c}-0.1752 * * * \\
(0.0651)\end{array}$ \\
\hline$(\text { ln unemployment rate })^{2}$ & $\begin{array}{l}0.0106^{*} \\
(0.0058)\end{array}$ & $\begin{array}{r}0.0112^{*} \\
(0.0058)\end{array}$ & $\begin{array}{r}0.0712 * * \\
(0.0286)\end{array}$ \\
\hline $\begin{array}{l}\text { (ln unemployment rate) x Accessibility/Agglomeration } \\
\text { measure }\left(A_{j t}\right)\end{array}$ & $\begin{array}{c}0.0793 * * * \\
(0.0265)\end{array}$ & & \\
\hline $\begin{array}{l}\text { (ln unemployment rate) x Accessibility/Agglomeration } \\
\text { measure }\left(T_{j t}\right)\end{array}$ & & $\begin{array}{r}0.0598 * * \\
(0.0246)\end{array}$ & $\begin{array}{l}0.1208 * * * \\
(0.0417)\end{array}$ \\
\hline $\begin{array}{l}\text { (ln unemployment rate) x (Spatial lag of } \ln \\
\text { unemployment rate) }\end{array}$ & & & $\begin{array}{r}-0.0678^{* *} \\
(0.0289)\end{array}$ \\
\hline Accessibility/Agglomeration measure $\left(A_{j t}\right)$ & $\begin{array}{l}0.4823 * * * \\
(0.1554)\end{array}$ & & \\
\hline Accessibility/Agglomeration measure $\left(T_{j t}\right)$ & & $\begin{array}{r}0.7104 * * * \\
(0.1711)\end{array}$ & $\begin{array}{l}0.7391 * * * \\
(0.1818)\end{array}$ \\
\hline Spatial lag of ln unemployment rate & & & $\begin{array}{r}0.1368 * * \\
(0.0595)\end{array}$ \\
\hline Constant & $\begin{array}{r}5.2695^{* * *} \\
(0.1051)\end{array}$ & $\begin{array}{r}5.2340^{* * *} \\
(0.1058)\end{array}$ & $\begin{array}{r}5.1546^{* * *} \\
(0.1110)\end{array}$ \\
\hline $\mathrm{O}$ & 2289 & 2289 & 2289 \\
\hline Number regions & 327 & 327 & 327 \\
\hline Pseudo $R^{2}$ within & 0.5975 & 0.5993 & 0.5817 \\
\hline Spatial $L M$ on $e_{j t}$ & $4.9964 * *$ & $4.7536^{* *}$ & 2.3037 \\
\hline $\begin{array}{l}\text { Standard errors in parentheses. * significant at } 10 \% ; * * \text { sig, } \\
\text { All models include time dummies. Other control variab } \\
\text { employment in firms with less than } 20 \text { employees, the sha } \\
\text { workers employed in agriculture. To save space the co } \\
\text { reported here, but are available from the authors on reques }\end{array}$ & $\begin{array}{l}\text { nt at } 5 \% ; * * * \\
\text { re the share } \\
\text { less educated } \\
\text { ients of the }\end{array}$ & $\begin{array}{l}\text { * significant a } \\
\text { of women, } \\
\text { d workers an }\end{array}$ & $\begin{array}{l}1 \% \\
\text { he share of } \\
\text { the share of } \\
\text { les are not }\end{array}$ \\
\hline
\end{tabular}


Table 4: Significance tests for spatial non-stationarity

\begin{tabular}{|c|c|c|c|c|c|c|c|}
\hline Variable & 1991 & 1992 & 1993 & 1994 & 1995 & 1996 & 1997 \\
\hline \multirow[t]{2}{*}{ Constant } & 0.1491 & 0.0887 & $0.3298 * * *$ & $0.3834 * *$ & $0.4305^{* * *}$ & 0.1221 & $0.7107 * * *$ \\
\hline & $(0.114)$ & $(0.645)$ & $(0.010)$ & $(0.019)$ & $(0.006)$ & $(0.527)$ & $(0.000)$ \\
\hline \multirow[t]{2}{*}{ In unemployment } & $0.1052 * *$ & 0.0824 & $0.3948 * * *$ & $0.3587 * *$ & $0.3914 * * *$ & 0.0938 & $0.6451 * * *$ \\
\hline & $(0.017)$ & $(0.428)$ & $(0.000)$ & $(0.032)$ & $(0.006)$ & $(0.603)$ & $(0.000)$ \\
\hline \multirow[t]{2}{*}{$(\ln \text { unemployment })^{2}$} & $0.0346 * *$ & 0.0275 & $0.1009 * * *$ & $0.0875^{* *}$ & $0.0975 * * *$ & 0.0203 & $0.1387 * * *$ \\
\hline & $(0.012)$ & $(0.299)$ & $(0.000)$ & $(0.025)$ & $(0.005)$ & $(0.628)$ & $(0.000)$ \\
\hline \multirow[t]{2}{*}{ (ln unemployment rate) x Accessibility/Agglomeration measure $\left(\mathrm{T}_{\mathrm{jt}}\right)$} & 0.0424 & 0.0664 & 0.0891 & 0.0595 & 0.1617 & 0.0465 & 0.0348 \\
\hline & $(0.559)$ & $(0.315)$ & $(0.237)$ & $(0.317)$ & $(0.103)$ & $(0.610)$ & $(0.858)$ \\
\hline \multirow[t]{2}{*}{ Accessibility/Agglomeration measure $\left(\mathrm{T}_{\mathrm{jt}}\right)$} & 0.0943 & 0.1261 & 0.1340 & 0.1184 & 0.3013 & 0.0954 & 0.0862 \\
\hline & $(0.388)$ & $(0.309)$ & $(0.517)$ & $(0.407)$ & $(0.202)$ & $(0.713)$ & $(0.836)$ \\
\hline \multirow[t]{2}{*}{ Share of women } & 0.0607 & 0.0724 & 0.1417 & 0.0554 & $0.1505 * *$ & $0.1007 * *$ & 0.0525 \\
\hline & $(0.484)$ & $(0.314)$ & $(0.013)$ & $(0.307)$ & $(0.027)$ & $(0.036)$ & $(0.405)$ \\
\hline \multirow[t]{2}{*}{ Share of small firms } & 0.0444 & 0.0454 & 0.0427 & 0.0359 & 0.0289 & 0.0319 & 0.0159 \\
\hline & $(0.548)$ & $(0.494)$ & $(0.519)$ & $(0.475)$ & $(0.972)$ & $(0.508)$ & $(0.910)$ \\
\hline \multirow[t]{2}{*}{ Share of less educated workers } & $0.1707^{*}$ & $0.1500^{*}$ & 0.0724 & 0.0810 & 0.1829 & 0.0868 & 0.067 \\
\hline & $(0.067)$ & $(0.090)$ & $(0.501)$ & $(0.103)$ & $(0.027)$ & $(0.123)$ & $(0.221)$ \\
\hline \multirow[t]{2}{*}{ Share of employed in agriculture } & 0.2821 & 0.1278 & 0.1975 & 0.2453 & $1.0179 * * *$ & 0.3746 & 0.1998 \\
\hline & $(0.622)$ & $(0.953)$ & $(0.802)$ & $(0.429)$ & $(0.001)$ & $(0.216)$ & $(0.651)$ \\
\hline
\end{tabular}


Table 5: Controlling for rural-urban heterogeneity in the wage curve

\begin{tabular}{|c|c|c|c|c|c|c|}
\hline Dependent Variable: ln wage & $\begin{array}{l}\text { Regions with } \\
\text { Strong } \\
\text { Agglomeration }\end{array}$ & $\begin{array}{c}(1) \\
\text { 2SLS-FE } \\
\text { Regions with } \\
\text { Weak } \\
\text { Agglomeration }\end{array}$ & $\begin{array}{c}\text { Regions with } \\
\text { No } \\
\text { Agglomeration }\end{array}$ & $\begin{array}{l}\text { Regions with } \\
\text { Strong } \\
\text { Agglomeration }\end{array}$ & $\begin{array}{c}(2) \\
\text { 2SLS-FE } \\
\text { Regions with } \\
\text { Weak } \\
\text { Agglomeration }\end{array}$ & $\begin{array}{c}\text { Regions with } \\
\text { No } \\
\text { Agglomeration }\end{array}$ \\
\hline \multirow[t]{2}{*}{ In unemployment rate } & -0.0336 & -0.0375 & $-0.2258 * * *$ & 0.0005 & -0.5013 & $-0.6488^{* *}$ \\
\hline & $(0.0256)$ & $(0.0417)$ & $(0.0697)$ & -0.0655 & -0.4211 & -0.3013 \\
\hline \multirow[t]{2}{*}{$(\text { ln unemployment rate })^{2}$} & 0.0082 & 0.0041 & $0.0590 * * *$ & -0.0202 & 0.2215 & $0.2569 * *$ \\
\hline & $(0.0075)$ & $(0.0113)$ & $(0.0192)$ & -0.033 & -0.1894 & -0.1289 \\
\hline (ln unemployment rate) $x$ Accessibility/ & $0.0992 * * *$ & 0.0553 & 0.0552 & $0.0912 * *$ & 0.2141 & 0.2927 \\
\hline Agglomeration measure $\left(\mathrm{T}_{\mathrm{jt}}\right)$ & $(0.0339)$ & $(0.0448)$ & $(0.0602)$ & -0.0416 & -0.1649 & -0.1791 \\
\hline (ln unemployment rate) $\times$ (Spatial lag of $\ln$ & & & & 0.0388 & -0.2183 & $-0.1978 *$ \\
\hline unemployment rate) & & & & -0.0388 & -0.1819 & -0.115 \\
\hline \multirow{2}{*}{ Accessibility/Agglomeration measure $\left(\mathrm{T}_{\mathrm{jt}}\right)$} & $0.8096^{* * *}$ & 0.2223 & $0.9468^{*}$ & $0.8544 * * *$ & 0.378 & $1.4592 *$ \\
\hline & $(0.2323)$ & $(0.3435)$ & $(0.5110)$ & -0.2407 & -0.4498 & -0.7554 \\
\hline \multirow[t]{2}{*}{ Spatial lag of ln unemployment rate } & & & & -0.0581 & 0.4615 & $0.3996^{*}$ \\
\hline & & & & -0.0736 & -0.3859 & -0.2313 \\
\hline \multirow[t]{2}{*}{ Constant } & $5.1594 * * *$ & $5.8855^{* * *}$ & $5.5905^{* * *}$ & $5.1891 * * *$ & $5.2454 * * *$ & $4.9034 * * *$ \\
\hline & $(0.1444)$ & $(0.3075)$ & $(0.3787)$ & -0.1523 & -0.684 & -0.5799 \\
\hline Observations & 826 & 686 & 630 & 826 & 686 & 630 \\
\hline Number regions & 118 & 98 & 90 & 118 & 98 & 90 \\
\hline Pseudo $\mathrm{R}^{2}$ within & 0.5867 & 0.6507 & 0.5891 & 0.5823 & 0.4332 & 0.3078 \\
\hline Spatial LM on $\mathrm{e}_{j t}$ & & $3.7951^{*}$ & & & 0.7707 & \\
\hline
\end{tabular}

Standard errors in parentheses. * significant at $10 \% ; * *$ significant at $5 \% ; * *$ significant at $1 \%$

All models include time dummies. Other control variables are theshare of women, the share of firms with less than 20 employees, the share of less educated workers and the share of workers employed in agriculture. To save space the coefficients of the control variables are not reported here, but are available from the authors on request. Such coefficients are almost all significant and all have the right sign. 


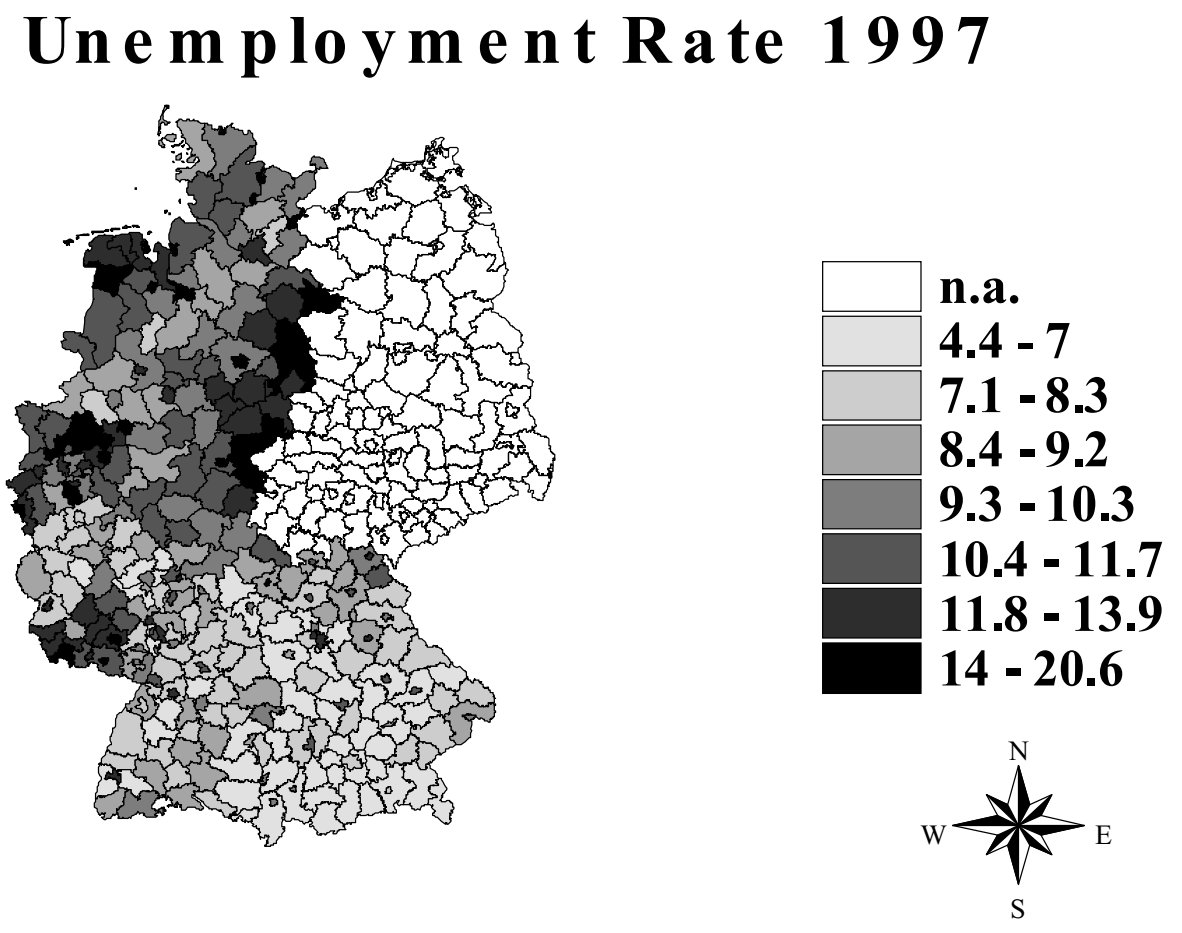

Figure 1: Regional unemployment rates in western Germany, 1997 

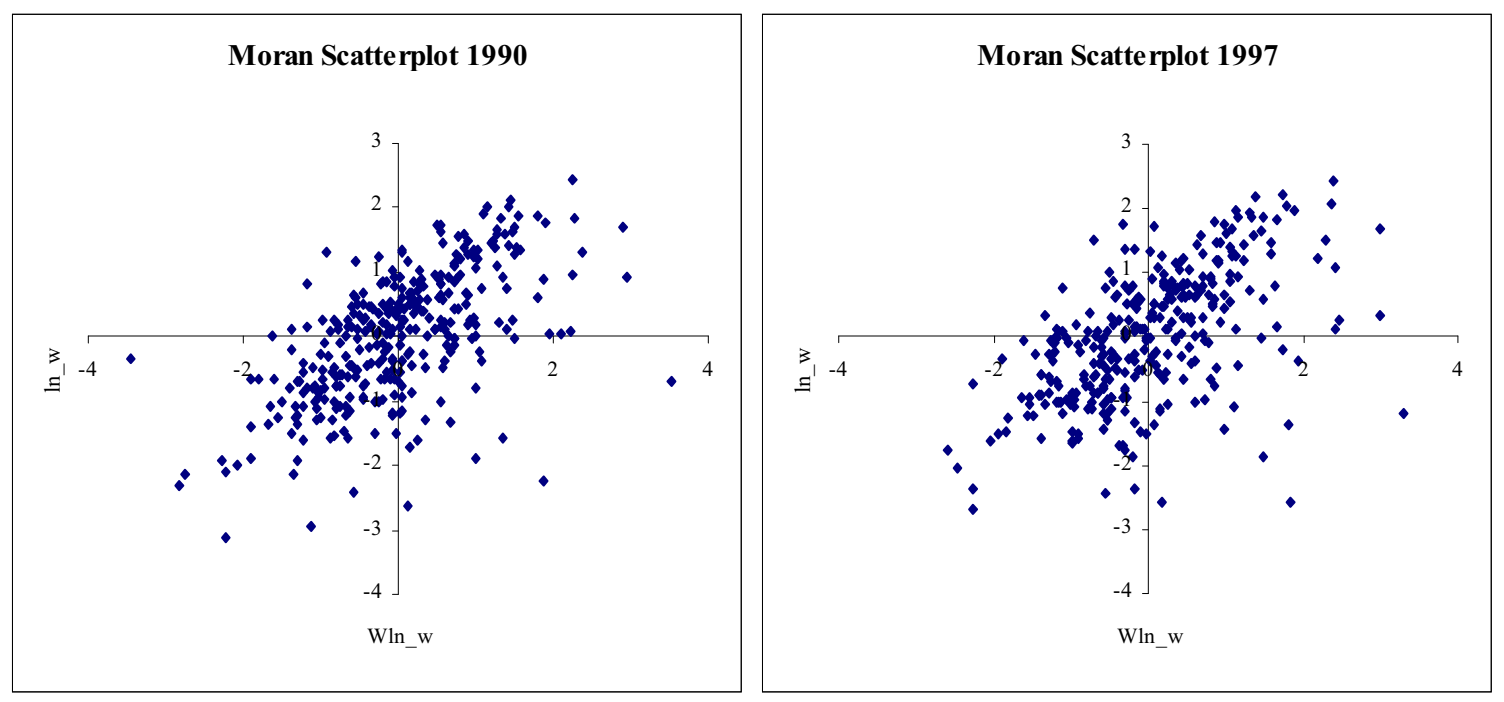

Figure 2: Moran scatterplot of log wages
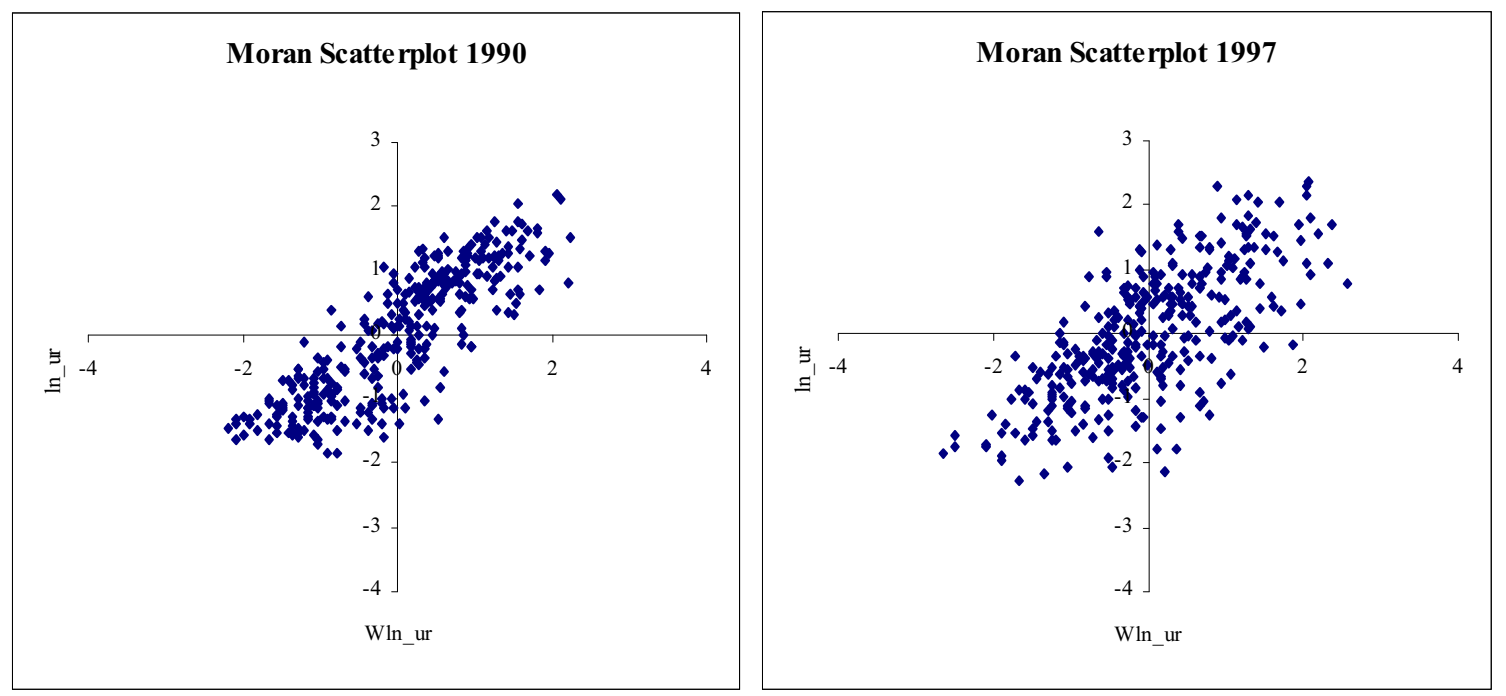

Figure 3: Moran scatterplot of log unemployment rate 


\section{Annex}

The data set used in this application was provided by the German Institute for Employment Research (Institut für Arbeitsmarkt und Berufsforschung - IAB), and contains information about wages, unemployment rates and employment in western Germany, aggregated at the level of 327 regions (Berlin is excluded from the data set). Specifically:

Wage: the data refer to gross daily wages per (full time) employee, in the period 1987-1997. and have been deflated using OECD data on the consumer price index for the whole of Germany, available on line at: http://www.oecd.org/EN/statistics/0, EN-statistics-3-nodirectorate-no-1--3,00.html. Trainees and workers with wages lower than $12 \mathrm{DM}$ a day are not included in the data set.

Unemployment rate: persons unemployed and seeking work as a percentage of labour force, 19902000.

Employment: the data refer to people gainfully employed in 327 regions of western Germany on any $30^{\text {th }}$ of June, and covered by the social insurance system. Statistics are based on location of the workplace. Low-income workers (see above) and civil servants are not included. The number of workers may be broken down by gender, size of the establishment and level of education. On the basis of this information we computed the control variables using the different classifications of the number of employees in the following way:

Share of women: percentage of female workers among the total number of employees in each region and each year. This variable ranges from $25 \%$ to $52 \%$.

Share of workers employed in firms: workers employed in firms with less than 20 employees, as a percentage of the total number of employees of each region and each year. This variable ranges from $8 \%$ to $51 \%$.

Share of less educated workers: percentage of workers with only (i) lower secondary school; (ii) intermediate (secondary) school without vocational training; and (iii) intermediate (secondary) school with vocational training, among the total number of employees in each region and each year. This variable ranges from $73 \%$ to $97 \%$.

Share of workers employed in agriculture: percentage of workers employed in firms classified in the agricultural sector. This variable ranges from $0.10 \%$ to $8.59 \%$.

Type of region: this information is based on the BfLR/BBR (Bundesforschungsanstalt für Raumordnung und Landeskunde / Bundesanstalt für Bauwesen und Raumordnung, Bonn) typology. The classification is computed according to the population and to the centrality of the location of each region (see Bellman and Blien, 2001). More in detail, the three groups used in this paper comprise the following regions:

A. Regions with urban agglomeration (118 regions)

1. Central cities (39 regions)

2. Highly urbanised regions (42 regions)

3. Urbanised region (23 regions)

4. Rural regions (14 regions)

B. Regions with tendencies towards agglomeration (119 regions)

5. Central cities (21 regions)

6. Highly urbanised regions (61 regions)

7. Rural regions (37 regions)

C. Regions with rural features (90 regions)

8. Urbanised regions (43 regions)

9. Rural regions (47 regions)

Weight matrix: the matrix contains the inverse of the Euclidean distances between location of region authorities in contiguous regions, computed from a digitalised map. Distance between non contiguous regions is assumed to be infinite, and the correspondent element of the matrix is therefore zero (see Buettner, 1999b). 